\title{
RISK ANALYSIS OF ONION FARMING
}

\author{
Febri Eugene $^{1)}$; Melli Suryanty ${ }^{2)}$; Nyayu Neti Arianti ${ }^{2)}$ \\ ${ }^{1)}$ Study Program of Agricultural Socio-Economics, Faculty of Agriculture, \\ University of Bengkulu \\ 2) Department of Agricultural Socio-Economics, Faculty of Agriculture, University of \\ Bengkulu \\ Email: ${ }^{2)}$ msuryanty@unib.ac.id
}

\begin{abstract}
How to Cite :
Eugene, F., Suryanty, M, Arianti N. N., 2019. Risk Analysis of Onion Farming in Marbun Tonga Marbun Dolok Village Baktiraja Subdistrict North Sumatera Province. Journal of Agri Socio-Economics and Business. 1 (1): 1-12. DOI: https://doi.org/10.31186/jaseb.1.1.45-51
\end{abstract}

\section{ARTICLE HISTORY \\ Received [2019-08-25] \\ Revised [2019-09-07] \\ Accepted [2019-11-25]}

\section{KEYWORDS \\ Onion, \\ risk, \\ level of risk}

This is an open access article under the $\underline{C C-B Y-S A}$ license

\section{ABSTRACT}

The purpose of this research are to identify the factors that cause the emergence of risk in onion farming based on the perceptions of farmers, to know the level of production, costs, and income of onion farming, determine the level of risk for production, costs, and income of onion farming, and to analyze onion farmers in the face of production risks. The method of determining the location is purposive method and the method of determining respondents is the census method. Data analysis methods are qualitative and quantitative. The results of the study show the average production of onion is $5,747 \mathrm{Kg} / \mathrm{MT} / \mathrm{Ha}$, the average farming cost is Rp. 74,515,798 MT / Ha, and the average income is Rp. 69,868,313 MT / Ha. The level of risk for production, costs, and income is included in the low category.

\section{INTRODUCTION}

In Indonesia, consumption of onion will continue to increase from year to year in line with an increase in the economic standard of life of the community. Based on consumption data of onion in Indonesia in the following table. 
Table 1. Consumption of Onion in Households in Indonesia Year 2013-2017

\begin{tabular}{ll}
\hline Year & Consumption/Capita/Year (Ounce) \\
\hline 2013 & 20,649 \\
2014 & 24,872 \\
2015 & 27,114 \\
2016 & 28,261 \\
2017 & 25,701 \\
\hline
\end{tabular}

Source: Ministry of Agriculture (2019)

Consumption data for the last 5 years shows that consumption of onion in households was greatest in 2016 of 28,261 ounces / capita / year and the lowest in 2013 was 20,649 ounces / capita / year. The need for onion consumption will continue to increase along with the increase in population in Indonesia. Onion consumption which continues to increase from year to year, it is necessary to hold efforts to increase production through human and natural resources.

Marbun Tonga Marbun Dolok Village, located in Baktiraja Subdistrict, is a village with a harvest area of $217.93 \mathrm{Ha}$ after Marbun Toruan Village, but red onion farming is carried out by many people in Marbun Tonga Marbun Dolok Village compared to Marbun Toruan Village (Baktiraja Subdistrict in Figures , 2018)

The fluctuation in onion production in 2018 indicates the production risks faced by onion farmers in this village. Last year there was also a crop failure due to red onion seed varieties that were not suitable for planting in this area. The use of inputs that are not the same every time and is not right is one of the factors causing changes in the production of onion farming. Besides the uncertain weather factors in this area that cannot be determined by farmers become a risk factor for onion farmers in this village such as continuous rain that cannot be controlled by farmers, besides the pests that often damage the onion plants become a hindrance to production onion in this village.

Every onion farmer expects high production and adequate income. In the face of uncertain environmental conditions, a farmer must be able to allocate the factors of production used in such a way that his farm can reach an efficient level and earn enough income to support his family and at the same time develop his farm.

Based on this background, the purpose of this study is to determine the level of production, costs, and income of onion farming, and calculate the level of risk of production, costs, and income of onion farming. 


\section{RESEARCH METHODS}

\section{Method of Collecting Data}

This research was conducted in Marbun Tonga Marbun Dolok Village, Baktiraja District, North Sumatra Province. Determination of this location is done intentionally (purposive). This research was conducted for one month, namely March-April 2019.

Determination of the respondents in this study was done deliberately (purposive), namely choosing a farmer group in the village. Respondents who will be taken are all members of the farmer group Ria Tani and Rukun Damai, as many as 37 people who actively grow onion in Marbun Tonga Marbun Dolok Village Baktiraja District.

Data analysis methods used in this study are qualitative analysis and quantitative analysis. This farming analysis is used to answer the first research objective, which is to determine the level of production, costs and income of onion farming. Meanwhile, the magnitude of the risk of onion farming in Marbun Tonga Marbun Dolok Village is analyzed using the following formula:

\section{Expected Results (E)}

The expected yield is calculated from the average value of the factors to be measured, namely production factors, cost factors, and income factors at each onion planting season with the formula:

$$
E=\frac{\sum_{i=1}^{n} E i}{n} \text { (Hermanto, } 1989 \text { dan Unsursan dalam Wiranti, 2016) }
$$

\section{Risk Level}

To systematically measure farm risk, variance or standard deviation is often used. With the following formula:

$$
V^{2}=\frac{\sum_{i=1}^{n}(E i-E)}{(n-1)}(\text { Kadarsan, 1995) }
$$

Standard deviation is the root of the variety with the formula:

$$
V=\sqrt{V^{2}}
$$

\section{Risk Coefficient}

The risk coefficient can be calculated using the formula:

$$
C V=\frac{V}{E} \quad \text { (Kadarsan, 1995) }
$$

Measurement of the level of risk can be determined using the following criteria (Zuhriyah and Happy, 2012; Fauziyah, 2010; Saptana et al., 2010): (a) If CV $\leq 0.5$ means that it has a small risk (b) If $0.5<\mathrm{CV} \leq 1$ and (c) If $\mathrm{CV}>1$ means that you have a big risk.

\section{Lower Limit (L)}

Tiera (2012) lower limit of the highest yield is the lowest possible yield value. The lower limit can be calculated with the following formula:

$$
L=E-2 V
$$

Where:

$\mathrm{L}=$ Lower limit on production, costs, revenues, income, prices

$E=$ Average value of production $(\mathrm{kg})$, costs $(R p)$, revenue $(R p)$, income $(R p)$ and price (Rp)

$\mathrm{V}=$ Standard deviation 
Measurement of the lower limit can be determined using the following criteria (Tiera, 2012):

- $\mathrm{L}>0$, meaning that most likely will experience a loss

- $\mathrm{L}<0$, meaning that it is likely to avoid loss

\section{RESULTS AND DISCUSSION}

\section{Analysis of Onion Farming in Marbun Village, Marbun Dolok}

Table 2.

To find out the average cost of onion farming issued by farmers can be seen in

Table 2. Average Costs of Onion Farming in the Marbun Village of Tonga Marbun Dolok

\begin{tabular}{lrr}
\hline \multicolumn{1}{c}{ Cost Type } & Amount of Cost (Rp/MT/UT) & Amount of cost (Rp/Mt/Ha) \\
\hline Seed Cost & 1.908 .973 & 15.435 .995 \\
Fertilizer Cost & 778.518 & 6.555 .357 \\
Pesticide Cost & 400.243 & 4.076 .468 \\
Family labour Cost & 3.265 .405 & 41.805 .887 \\
Out of family labour costs & 456.486 & 3.502 .027 \\
Operating Cost & 235.946 & 1.799 .444 \\
Total Variable Cost & $\mathbf{7 . 0 4 5 . 5 7 1}$ & $\mathbf{7 3 . 1 7 5 . 1 7 8}$ \\
Tool Depreciation Cost & 88.675 & 879.539 \\
Tax/Rental Cost & 62.765 & 461.081 \\
Total Fixed Cost & $\mathbf{1 5 1 . 4 4 0}$ & $\mathbf{1 . 3 4 0 . 6 2 0}$ \\
\hline Total Cost & $\mathbf{7 . 1 9 7 . 0 1 1}$ & $\mathbf{7 4 . 5 1 5 . 7 9 8}$ \\
\hline
\end{tabular}

Source: Primary data processed (2019)

With an average production of 5,747 $\mathrm{kg} / \mathrm{MT} / \mathrm{ha}$, farmer revenues, total costs, and income for more details can be seen in Table 3 .

48 |Eugene, F; Suryanty, M; Arianti, N N; Risk Analysis Of Onion Farming ... 
Table 3. Average Revenue, Total Cost and Income of Onion Farming in Marbun Village, Marbun Dolok

\begin{tabular}{lll}
\hline Description & Amount $(\mathrm{Rp} / \mathrm{MT} / \mathrm{UT})$ & Amount $(\mathrm{Rp} / \mathrm{MT} / \mathrm{Ha})$ \\
\hline Reception & 18.552 .703 & 144.384 .111 \\
Total Cost & 7.197 .012 & 74.515 .798 \\
Income & 11.355 .691 & 69.868 .313 \\
\hline
\end{tabular}

Source: Primary data processed (2019)

Based on table 3 it can be seen that the average receipt of onion farming by farmers is Rp. 144,384,111 / MT / Ha. The results of the analysis of the production costs of onion farming showed that the average total cost incurred by farmers was Rp $74,515,798 \mathrm{MT} / \mathrm{Ha}$ in one planting season. The cost components in this farm include variable costs and fixed costs. Of the eight components of costs incurred by farmers in onion farming, the highest allocation of costs is labor costs in the family of $56.10 \%$ of the total costs incurred by farmers. Then $43.90 \%$ is a component of costs outside of labor in the family. In table 2 it can be seen that the average income earned by farmer group members is Rp. 69,868,313 MT / Ha.

\section{Risk Analysis of Onion Farming}

The calculation of the magnitude of production risk, cost risk and risk of onion farm income can be seen in Table 4.

Table 4. Risk Level of Production, Costs, and Income of Onion Farming in Marbun Tonga Marbun Dolok Village

\begin{tabular}{clccc}
\hline No & Risk & CV Value & L Value & Risk Level \\
\hline 1 & Production & 0,013416 & 5.595 & Low \\
2 & Cost & 0,000116 & 74.498 .533 & Low \\
3 & Reception & 0,000083 & 144.360 .079 & Low \\
4 & Income & 0,000120 & 69.851 .596 & Low \\
5 & Price & 0,006304 & 24.844 & Low \\
\hline
\end{tabular}

Source: Primary data processed (2019)

In the calculation of the CV value contained in table 4, it can be concluded that the risk of onion farming production is higher than the CV value of the cost, revenue, income and price risk that is equal to 0.013416 and the $\mathrm{CV}$ value is smaller than 0.5 
The calculation of the CV value of the cost obtained is 0,000116 or equal to 0 , meaning that for every $1 \mathrm{Ha}$ of land cultivated by onion farmers will produce a risk of 0 $R p$ or it can be said that onion farmers always avoid loss. Calculation of $L$ value obtained is $74,498,533 \mathrm{Rp} / \mathrm{ha}$, the figure shows that the minimum cost to be incurred by onion farmers during one growing season

The CV value of the onion farm receipts is equal to 0.000083 or equal to 0 . The coefficient of variation on the revenue obtained means that for every 1 hectare of land cultivated by onion farmers will result in an acceptance risk of $0 \mathrm{Rp}$. Calculation of the value of the lower limit of this revenue is $144.360 .079 \mathrm{Rp} / \mathrm{Ha}$ means the minimum acceptance limit that must be received by onion farmers in this farm is $144.360 .079 \mathrm{Rp}$ / ha.

The CV value obtained from onion farm income is 0,00012 , meaning that for every $1 \mathrm{Ha}$ of onion farm area cultivated by farmers will result in a risk of income of $0,00012 \mathrm{Rp}$. The lower limit value of the income obtained is $69,851,596 \mathrm{Rp} / \mathrm{ha}$, meaning that the figure shows the minimum income limit obtained from onion farming in order not to experience a loss of $69,851,596 \mathrm{Rp} / \mathrm{ha}$.

The CV value of the price of 0.001813 means that for every 1 hectare of land cultivated by onion farmers will produce a risk of 0.006304 . With the calculation of the lower limit value obtained at $24,844 \mathrm{Rp} / \mathrm{kg}$. This means that the figure shows the minimum price limit received by onion farmers is $24,844 \mathrm{Rp} / \mathrm{kg}$ in one planting season.

\section{CONCLUSIONS AND RECOMMENDATIONS}

\section{CONCLUSIONS}

Based on the research results of risk analysis of onion farming in Marbun Tonga Marbun Dolok Village, Baktiraja District, North Sumatra Province, it can be concluded that the average level of onion production by members of the Ria Tani and Rukun Damai groups is $5,747 \mathrm{Kg} / \mathrm{MT} / \mathrm{Ha}$, the average the cost used in onion farming is IDR $74,515,798 \mathrm{MT} / \mathrm{Ha}$, and the average income of members of the farmer group is IDR 69,868,313 MT / Ha.

The level of risk of production, costs, and income of onion farming by members of the Ria Tani and Rukun Damai Group in Marbun Village, Marbun Dolok is included in the low category.

\section{RECOMMENDATIONS}

Based on the research results of the analysis of the risk of onion farming in Marbun Village, Tonga and Marbun Dolok, Baktiraja District, North Sumatra Province, it is recommended that farmers expand their land so that they can increase their income from onion farming.

The level of risk of onion farming in Marbun Tonga Marbun Dolok Village is included in the low category and measurement of the lower bound value obtained shows that onion farming is protected from loss or risk, but it is necessary to introduce efforts to increase added value and new technologies in onion farming red. 


\section{REFERENCES}

Andriyani, Wiwid. 2014. Analysis of Production and Revenue of Tinombo Local Shallots Farming in Lombok Village, Tinombo District, Parigi Motung Regency. e-J. Agrotekbis 2 (5): 537-538.

Asih, Dewi Nur. 2009. Analysis of Characteristics and Level of Income of Shallots Farming in Central Sulawesi. J. Agroland.16 (1): 53-59

Humbang Hasundutan Central Statistics Agency. 2018. Subdistrict of Baktiraja in Figures 2018. Regency of Humbang Hasundutan: Statistics Indonesia

Budiningsih, Sulistyani and Pujiharto. 2006. Risk Analysis of Shallot Farming in Klikiran Village, Jatirambang District, Brebes Regency. Agritech. 8 (1): 134135

Fauzan, Muhammad. 2016. Revenue, Risk and Economic Efficiency of Shallot Farming in Bantul Regency. Agribusiness Journal. 2 (2): 111-113.

Felycia Tiera Kencana, Ketut Sukiyono, and Bambang Sumantri. Pattern Analysis and Risk of Palm Sugar Business in Rejang Lebong Regency. Journal of AGRISEP. 11 (1): 1 - 11.

Kadarsan, H.W.1995. Agribusiness Companies Finance and Agriculture Financing. Gramedia Main Library. Jakarta

Ministry of Agriculture. 2019. Consumption of Shallots in Households per Capita in Indonesia 2013-2017 Indonesia: Ministry of Agriculture of the Republic of Indonesia

Rarasati Christiani Indah, Joko Sutrisno, R.R. Aulia Qonita. 2015. Risk Analysis on Soybean Farming in Gobongan Regency. Agrista. 3 (2): 45-55

Robison LJ and Barry PJ. 1987. The Competitive Firm's Response to Risk. London (UK): Collier Macmillan Publishers.

Soekartawi. 2002. Farm Analysis. Universitas Indonesia Press. Jakarta 